\title{
EU Financial Market Governance and the Covid-19 Crisis: ESMA’s Nimble, Responsive, and Speedy Response in Coordinating National Authorities through Soft-Law Instruments
}

\author{
by \\ NiAmH MoloneY* \\ and \\ Pierre-Henri Conac**
}

The initial evidence indicates that EU financial market governance has performed well in its response to the Covid-19 crisis. In the European Union (EU), the need for coordination and cooperation over this crisis has been a particular concern given that national competent authorities (NCAs) operate under the single rulebook and supervisory action must, accordingly, be consistent. The European Securities and Markets Authority (ESMA) has, however, shown itself to be nimble, responsive, and speedy in deploying its supervisory powers, including those additional powers it has recently been granted under the 2019 ESA Reform Regulation. This has particularly been the case as regards the application by NCAs of 'supervisory forbearance' and as regards the application of market disclosures rules, notably the financial reporting standard IFRS 9. ESMA has also been successful in coordinating the few NCAs which decided to impose restrictions on short selling. ESMA's actions during the Covid-19 crisis underline the de facto power it wields through its soft supervisory convergence powers and the entrepreneurial but effective approach it deploys in their use. ${ }^{1}$

Table of Contents

ECFR 2020, 363-385

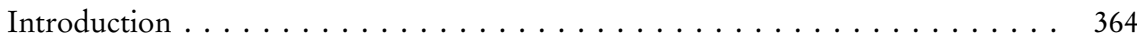

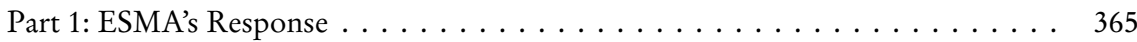

1.1 ESMA and Coordination $\ldots \ldots \ldots \ldots \ldots \ldots \ldots \ldots \ldots \ldots$

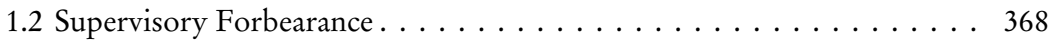

1.3 Market Disclosures . . . . . . . . . . . . . . . . . . . . . . . . . 373

1.4 An Effective Response . . . . . . . . . . . . . . . . . . . . 377

* Professor of Financial Markets Law and Head of Department, Law Department, London School of Economics and Political Science.

** Professor of Financial Markets Law at the University of Luxembourg.

1 See generally, Niamb Moloney, the Age of ESMA. Governing EU Financial Markets (Hart Publishing, 2018), chapter 4. 
Part 2: Short Selling Restrictions Introduced Across the EU and ESMA's Role in this Regard . . . . . . . . . . . . . . . . . . . . 377

2.1 The Regulatory Framework . . . . . . . . . . . . . . . . . . . . . . . 378

2.2 The Short Selling Restrictions Introduced Across the EU . . . . . . . . . 380

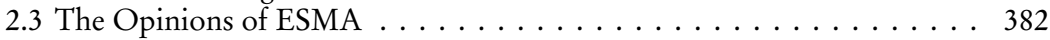

2.4 The Harmonisation Role of ESMA . . . . . . . . . . . . . . . . . . 384

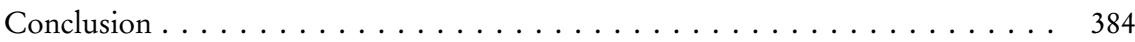

\section{Introduction}

This discussion sets out some initial reflections on how EU financial market governance has responded to the Covid-19 crisis. $^{2}$ EU financial market governance is no stranger to crisis. Most recently, the 2008-2012 financial/euroarea crisis radically recast how EU financial markets are regulated and supervised, significantly upgraded the EU's governance as regards the securing of financial stability, and materially enhanced the EU's coordination capacity by establishing the European Securities and Markets Authority (ESMA). By early 2020 the EU might reasonably have been regarded to be equipped with a resilient financial market governance framework capable of supporting the EU financial market through a crisis. As this note suggests, the initial evidence indicates that EU financial market governance has performed reasonably well under pressure. ${ }^{3}$ Looking to the future, however, there are grounds for concern. There is little evidence that capital markets in the EU will be able to fill the funding gap that the weight of non-performing loans across the EU banking sector is likely to create. ${ }^{4}$ There may also be long-term disruption to the EU's flagship Capital Markets Union (CMU) project. ${ }^{5}$ The depth of the EU's commitment to CMU is nonetheless clear. The important June 2020 report of the Commission's High Level Forum on the Capital Markets Union underlines that the EU's 'too bank-centric system' is a 'major bottleneck' for the EU

2 Niamb Moloney is primarily responsible for Part One and Pierre-Henri Conac is primarily responsible for Part Two.

3 For a wide-ranging review of the EU's response to Covid-19 and from a financial stability perspective see Christos Gortsos et al, Pandemic Crisis and Financial Stability, European Banking Institute Working Paper Series, 22 May 2020.

4 The European Banking Authority (EBA) has reported that asset quality is likely to deteriorate significantly in the medium term, although it is also of the view that regulators have taken action to ensure that banks' capacity to fund the real economy is not impaired: EBA, The EU Banking Sector: First Insights into the Covid-19 Impacts (2020) (EBA/ $\mathrm{REP} / 2020 / 17)$.

5 Karel Lannoo, Can Europe's Finance Sector Resist Covid-19? ECMI Commentary No 63, March 2020. 